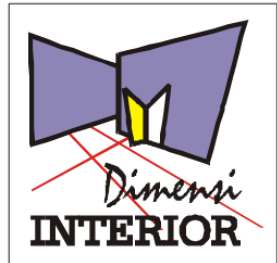

http://dimensiinterior.petra.ac.id

\title{
STUDY MATERIALITY DALAM APLIKASI MATERIAL UPCYCLE PADA DESAIN INTERIOR
}

\author{
I Kadek Dwi Noorwatha | I Wayan Balika Ika | I Nyoman Adi Tiaga \\ Program Studi Desain Interior, Institut Seni Indonesia Denpasar \\ email: noorwatha@gmail.com
}

\begin{abstract}
ABSTRAK
Materialitas (materiality) yang dapat diartikan sebagai pengaruh dan keberadaan material terhadap manusia dalam ruang interior khususnya material upcycle, keberadaannya semakin mengemuka di era kekinian. Material upcycle yang berasal dari limbah justru dijadikan nilai tambah materialitas dalam visualisasi desain interior ruang komersial. Penelitian ini bertujuan untuk mendapatkan perumusan tentang prinsip materialitas dalam aplikasi material upcycle pada desain interior. Penelitian ini menggunakan metode observasional dengan pendekatan kualitatif dengan membandingkan sumber literatur dan data lapangan, untuk mendapatkan suatu pemahaman sesuai dengan tujuan penelitian. Temuan penelitian menunjukkan adanya pertimbangan dalam memilih materialitas material upcycle dalam interior komersial di Bali, seperti: (1) Keunikan (2) Tekstur (3) Transformasi (4) Memorabilia dan (5) Kesesuaian dengan Konsep.
\end{abstract}

Kata Kunci: materialitas, material upcycle, desain interior

\begin{abstract}
Materiality that can be interpreted as the influence and the existence of material to humans in the interior space, especially upcycle material, its existence increasingly emerging in the present era. Upcycle material that comes from waste actually uses as materiality added value in visualization of interior design of commercial space. This study aims to obtain the formulation of the principle of materiality in the application of upcycle materials on interior design. This research uses observational method with qualitative approach by comparing source of literature and field data, to get an understanding in accordance with research objectives. The research findings indicate consideration in selecting material materiality of upcycle in commercial interior in Bali, such as: (1) Uniqueness (2) Texture (3) Transformation (4) Memorabilia and (5) Conformity with Concept.
\end{abstract}

Keywords: materiality, upcycle material, interior design

\section{PENDAHULUAN}

Desain interior sebagai sebuah keilmuan yang membahas tentang hubungan manusia dan ruang arsitektural tentu tidak terlepas dari pembahasan material dan materialitas sebagai salah satu elemen pembentuknya. Istilah materialitas (materiality) menjelaskan bagaimana pengaruh dan keberadaan material terhadap manusia dalam ruang interior. Oxford English Dictionary (1989) menyatakan bahwa materialitas dalam desain interior adalah konsep dari konsolidasi fisik materi yang dapat menginformasikan civitas tentang lingkungan yang melingkupinya. Material dalam lingkungan interior berpengaruh terhadap bagaimana pengalaman civitas terhadap ruang baik yang dihuni (inhabiting) atau hanya berinteraksi atau menguasai area tertentu (occupying) sementara. Material secara visual dan fisikal mempunyai suatu karakter visual dan bentuk tertentu yang mempengaruhi manusia secara psikologis maupun fisiologis. Material dalam konteks psikologis memberikan suatu persepsi tertentu pada manusia yang mempengaruhi manusia dalam persepsi pada ruang arsitektural.

Pembahasan mengenai material dalam perspektif materialitas dalam konteks desain interior dilakukan untuk mendapatkan pemahaman terhadap keindahan, keanggunan dan struktur dari material tersebut dalam aplikasinya pada desain baik interior maupun furnitur [1]. Setiap bahan memiliki sebuah nilai konotatif dan simbolik yang melekat secara instrinsik dan saling berhubungan dengan pengalaman manusia yang melibatkan baik pikiran dan tubuhnya. Koneksi yang dimiliki material dengan pengalaman manusia dapat menjadi sesuatu yang sangat subjektif atau memiliki asosiasi budaya yang luas. Konotasi manusia terhadap obyek yang terbuat dari kayu mungkin berbeda jauh dari yang dari objek yang sama terbuat dari logam atau kaca. Konotasi Kayu lebih kepada material yang natural dan cenderung tradisional klasik sedangkan logam dan kaca cenderung mengacu ke teknologi tinggi dan modernitas [2]. Pengalaman dan koneksi manusia terhadap material tersebut digunakan 
oleh desainer untuk menentukan konsep dan atmosfer ruang yang sesuai dengan kebutuhan desainnya. Dengan kata lain material dalam sisi tertentu berperan penting dalam memvisualisasikan konsep desain seorang desainer yang mengkonstruksi persepsi manusia sebagai pengguna ruang. Dari sisi fisiologis, keberadaan dan sifat material yang mempengaruhi aspek ragawi manusia baik aktivitas dan sentuhan langsungnya ke tubuh manusia. Pemilihan material dalam furnitur sebagai contoh, pemilihan material akan bersentuhan langsung dengan kulit dan indra peraba manusia. Dalam konteks interior material selain mempunyai karakter tertentu juga hendaknya dipertimbangkan aspek hubungan material tersebut terhadap tubuh biologis manusia yang berinteraksi dengannya dalam durasi waktu tertentu.

Dalam konteks material bekas pakai (upcycle) terjadi suatu diskursus materialitas dengan desain interior. Material bekas pakai khususnya kayu, dewasa ini eksistensinya semakin tinggi diaplikasikan sebagai material pembentuk interior. Material upcycle tersebut ada yang berupa per bagian (palet) dan utuh, yang akan ditransformasikan menjadi elemen pembentuk desain interior khususnya pada ruang komersial. Makin banyak ditemukan di Kota di Indonesia khususnya Kabupaten Badung di Provinsi Bali, pemanfaatan material tersebut banyak diterapkan di ruang komersial untuk pariwisata khususnya di kafe dan restoran. Mayoritas pemilik mengemukakan bahwa alasan memilih material upcycle pada dasarnya adalah sisi ekonomi, dimana material upcycle dirasakan lebih murah dibandingkan dengan material yang baru dan juga karakternya cukup unik untuk menarik minta pengunjung. Penggunaan material yang semakin banyak tersebut menciptakan tren tersendiri pada visualisasi desain interior ruang komersial tertentu, yang mencerminkan suatu visualisasi desain interior yang khas.

Seperti yang telah dipaparkan sebelumnya bahwa aspek material dalam desain mempengaruhi secara psikologis dan fisiologis manusia, maka pemanfaatan material upcycle tersebut perlu untuk dikaji lebih mendalam untuk mendapatkan formulasi dan pemahaman tentang material itu sendiri dan aplikasinya dalam desain interior. Berdasarkan hal tersebut tulisan ini menggunakan metode observasional dengan pendekatan kualitatif dengan membandingkan sumber literatur dan data lapangan, untuk mendapatkan suatu pemahaman sesuai dengan tujuan penelitian ini.

\section{TINJAUAN TENTANG MATERIAL UPCYCLE}

Pemanfaatan ulang (daur ulang) suatu material ataupun benda yang telah dipakai menjadi material atau bentuk baru dikenal dengan beberapa istilah yaitu recycle, reuse, reclaimed, downcycle dan upcycle. Kesemuanya itu mengacu pada suatu konsep pemanfaatan kembali produk termasuk didalamnya material pembentuknya yang telah dipakai, untuk dimaksimalkan kembali penggunaan. Dari beberapa istilah tersebut terdapat dua pengertian besar yang mengemuka yaitu recycle dan upcycle. Pada dasarnya pengertian dari istilah tersebut dalam bahasa Indonesia direpresentasikan dengan kata 'daur ulang', namun jika ditelaah secara kritis ada perbedaan mendasar antara kedua kata tersebut yang dijadikan rujukan dalam tulisan ini.

Proses upcycling berlawanan dengan recycle. Recycle yang secara umum dikenal sebagai proses memecah material (bekas) aslinya dan menjadikannya ke dalam sesuatu yang baru dengan menggunakan energi tertentu; sementara upcycling justru bermakna penghematan energi. Upcycling dan recycling, mempromosikan dampak positifnya pada lingkungan dan sumbernya [3]. Beberapa keuntungan yang ditawarkan oleh proses upcycling terhadap perikehidupan manusia dan lingkungannya serta yang melingkupinya, antara lain:

\section{a. Keberlanjutan (Sustainability)}

Keberlanjutan mengacu pada sebuah kegiatan untuk menciptakan sesuatu yang memiliki unsur kebaruan, yang mempunyai efek jangka panjang pada lingkungan. Dimana fungsi dari objek sebelumnya ditransformasikan menjadi sebuah cara baru dan kreatif dalam fungsinya. Bentuk asalnya menjadi berlanjut seperti aslinya atau dimanipulasikan dan dikombinasikan dengan fungsi objek yang lain.

\section{b. Kearifan Keberlingkungan (Environmental Wise)}

Produk upcycle biasanya bersifat ramah lingkungan ketika prosesnya dapat direpetisi, mengembalikan material ke bentuk dasarnya yang hasil akhirnya menjadi sumber baru proses selanjutnya. Jika seorang desainer cukup kreatif, suatu produk buangan tersebut dapat difungsikan kembali menjadi fungsi baru yang lain, memberikan sebuah "kehidupan" baru pada produk buangan tersebut.

\section{c. Pendekatan Kreatif (Creative Approach)}

Kegiatan upcycle merupakan sebuah usaha yang kreatif untuk menjaga kelangsungan lingkungan alam. Keindahan dari pendekatan ini adalah tetap mempertahankan nilai sentimental dari produk bekas, dibandingkan langsung dibuang ke tempat sampah, seseorang dapat menciptakan sesuatu yang baru dengan nilai estetik yang lebih tinggi. Sampah buangan yang dulunya tidak dihiraukan dan ditinggalkan, sekarang dapat ditambahkan nilai estetis tertentu dan ditingkatkan nilainya menjadi sesuatu yang lebih berharga [3].

Pernyataan di atas menegaskan bahwa proses upcycling menawarkan suatu nilai kreatifitas yang tinggi untuk mekreasikan dan merevitalisasi suatu produk buangan, menjadi suatu produk baru yang bernilai dnegan mempertahankan karakter produk sebelumnya. Desain interior khususnya dalam desain furnitur yang menggunakan material upcycle konsep dasar upcycle tersebut diterapkan dan dikombinasikan dengan metode desain. Proses upcycling, sama seperti proses desain lainnya, membutuhkan kemampuan untuk mengapreasiasi material dari produk buangan dan berusaha untuk mendorong batas-batas kemungkinan pengembangannya. Hal tersebut juga membutuhkan aspek komunikasi dan pengembangan pengetahuan melalui pengalaman dan eksperimen. Upcycling memberikan suatu potensi bagi interaksi fisikal dan potensi untuk mengembangkan pemahaman, baik yang melekat (inherent) pada produk yang telah ada dan suatu produk yang masih berupa 
abstraksi (yet-to-exist) dalam pemikiran desainer yang akan diwujudkan [4].

Proses upcycling dalam desain juga mengacu pada pemaknaan re-desain, yakni suatu proses yang berpatokan pada desain yang telah ada dan secara pragmatis berusaha menjawab kekurangan desain existing dan memaksimalkan potensi pengembangannya menjadi suatu produk ideal. Prinsip regenerasi desain dalam proses upcycle antara lain:

\section{1) Prinsip Penguatan Nilai (Value enhancing principles)}

Target utama dari proses upcycle adalah untuk mempromosikan nilai limbah dan mengubahnya menjadi produk yang bernilai ekonomis, sehingga meningkatkan nilai menjadi tujuan utamanya. Prinsip tersebut membutuhkan eksplorasi mendalam dari desainer dalam menggali nilai potensi limbah dari fungsi, material, struktur dan sebagainya, dan membuat yang terbaik darinya untuk memperkuat nilainya.

\section{2) Prinsip Tanpa Sisa (The principle of making the most use of the waste)}

Mendesain ulang dengan limbah sebagai bahan baku redesain harus mencoba berbagai eksperimen, sehingga menemukan metode yang terbaik untuk mengurangi bahan bekas dari proses manufaktur untuk memaksimalkan pemanfaatan material tersebut dan pengolahan material upcycle tersebut betul-betul memanfaatkan keseluruhan material dari produk sebelumnya.

\section{3) Prinsip Durabilitas dan Lingkungan (Durable and environmental principle)}

Meskipun bahan baku produk mendesain ulang berasal dari hal-hal yang terbuang atau 'tua', bukan berarti kualitas produk yang akan dihasilkan dari proses redesain menjadi rendah. Redesain material upcycle tidak serta seluruhnya menjadi produk temporer atau sesaat ( ad hoc) semata, tapi aspek kekuatan dan durabilitas produk sebelumnya juga ditingkatkan. Dalam konteks pencapaian durabilitas produk tersebut, desainer harus mempunyai kesadaran untuk memilih yang ramah lingkungan sebagai panduan desain dan menghindari pengaruh negatif material terhadap lingkungan. Kesadaran tersebut harus terintegrasi dalam proses desain produk, penggunaannya oleh konsumen dan daur ulang yang akan diberlakukan setelah produk tersebut telah habis pakai.

\section{4) Prinsip Kontrol Biaya (Cost control principle)}

Prinsip kontrol biaya lebih mengedepankan kesadaran untuk memaksimalkan proses produksi yang efisien dalam konteks biaya produksi untuk mendapatkan produk yang bernilai ekonomis tinggi. Hal tersebut untuk menghindari harga jual produk upcycle lebih mahal dari produk barunya. Hal tersebut diakibatkan oleh cost production yang terlalu tinggi tidak sebanding dengan nilai ekonomisnya.

\section{5) Prinsip Estetika Masyarakat (Populace's aesthetic principle)}

Kesadaran mengikuti 'estetika publik' adalah kesadaran desainer untuk merujuk pada aplikasi prinsip desain dalam komersialisasi atau selera masyarakat berkaitan dengan selera estetisnya. Berdasarkan prinsip tersebut, para desainer harus memiliki kualitas visual yang sempurna, wawasan yang tajam dan menjadi familiar dengan kondisi dan kebiasaan target pasar, serta peka dengan elemen visual yang popular dan sedang tren. Untuk mencapai pencapaian tertinggi dalam prinsip tersebut maka desainer hendaknya menghindari subjektifitas baik pemikiran dan nilai pribadi ke dalam desain dalam tujuan untuk menyesuaikan diri dengan pasar [5].

\section{MATERIALITAS DALAM DESAIN INTERIOR}

Sebagai salah satu lingkungan yang terbangun (built environment), pembahasan material sebagai unsur pembangun dalam desain interior menjadi salah satu isu esensial dalam perwujudan desain interior. Karakteristik material dalam desain interior menjadi salah satu elemen penting dalam perwujudan konsep dan visualisasi interior itu sendiri. Karakteristik material adalah:

a. Warna (color): karakteristik warna tergantung pada kualitas dan kuantitas cahaya; satu atau lebih warna produk bawaan asalnya dan warna tambahan jika dilakukan proses tambahan.

b. Daya tahan (durability): kemampuan untuk menahan kekuatan destruktif, mempertahankan penampilan asli, dan fungsi dasar sebagaimana rencana awal desain.

c. Elastisitas (elasticity): ketahanan atau fleksibilitas; kemampuan untuk kembali ke bentuk awal setelah deformasi.

d. Bentuk (form): kualitas tiga dimensional ditentukan oleh dimensi panjang; dimensi lebar dan kedalaman; potensi dikembangkan secara linear, planar atau blok.

e. Plastisitas (plasticity): kemampuan untuk dibentuk; memungkinkan deformasi terus menerus tanpa kerusakan pada struktur produk awal.

f. Perbaikan (refinement): kemampuan untuk dibentuk secara presisi, tipis, elemen berjarak dekat; tergantung pada kekuatan material, daya tahan, dan proses manufaktur

g. Kekuatan (strength): kemampuan untuk menahan tekanan, tekukan tanpa merusak material.

h. Tekstur (texture): kehalusan atau kekasaran relatif permukaan material; dalam skala besar maupun kecil

i. Potensi untuk dikembangkan (workability): kemudahan mengubah material dari bentuk utamanya [6].

Pemahaman tentang karakteristik material tersebut di atas dibutuhkan oleh seorang desainer interior dalam menentukan konsep desain. Sebuah konsep desain yang kuat menuntut integrasi dari berbagai pertimbangan desain. Dalam eksplorasi konsep tersebut dibutuhkan pengetahuan tentang desain dan konstruksi, pemilihan material yang berdasarkan keinginan untuk mengaktualisasikan konsep desain. Pengetahuan tentang material baik dari karakter, kontruksi dan finishing-nya dapat menginspirasi konsep desain dan pengembangan 
skematik desain, begitu juga sebaliknya konsep desain juga daat mempengaruhi pemilihan jenis dan karakteristik material untuk mencapai visualisasi tertentu pada tahap awal proses desain. Dalam pemilihan material tersirat juga pertimbangan terhadap penggunaan, aplikasi, dan detail yang dapat memperkuat prinsip-prinsip desain seperti ritme, repetisi, skala, proporsi, dan kesatuan dls, sehingga menciptakan keterkaitan antara ideologis desainer antara material, pengalaman spasial, dan intensi desain [2]. Dalam konteks visualisasi desain, material juga menciptakan suasana dan memberikan tekstur serta substansi arsitektur. Untuk memahami bagaimana menggunakan material tersebut efektif, desainer perlu memiliki pemahaman tentang preseden atau bagaimana bahan telah digunakan sebelumnya secara historis dan kesadaran inovasi dalam aplikasi material. Keduanya dapat memberikan cara yang berguna untuk mengembangkan berbagai pendekatan desain [7].

\section{APLIKASI MATERIAL UPCYCLE DALAM DESAIN INTERIOR KOMERSIAL}

Pembahasan selanjutnya akan diceksilang antara pedoman dalam literatur dengan aplikasinya di lapangan. Penetapan sampel digunakan judgmental sampling dengan memilih 4 interior komersial khususnya restoran yang menggunakan material upcycle dalam interiornya. Adapun yang dijadikan sampel dalam penelitian adalah beberapa kafe dan restoran di Bali khususnya di Kabupaten Badung yang memanfaatkan material upcycle khususnya kayu dalam desain interiornya.

\section{Man Shed, Sanur}

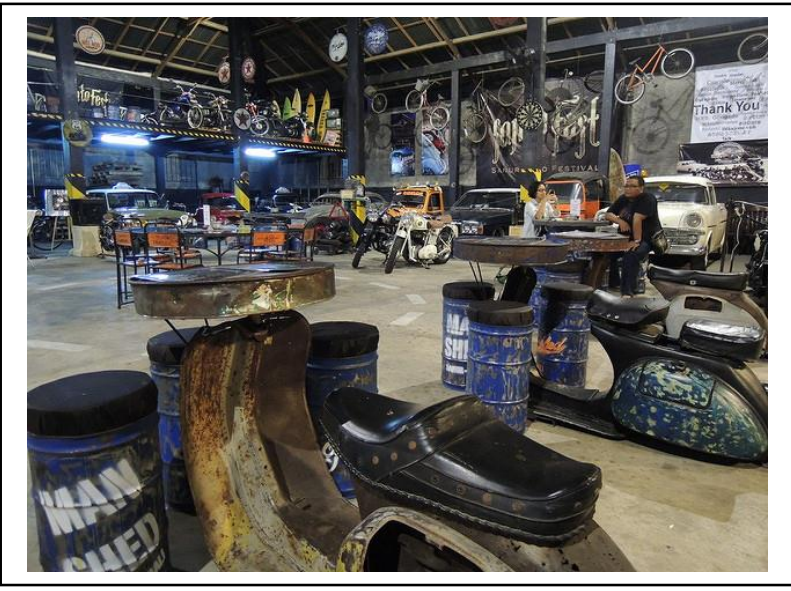

Gambar 1. Interior Man Shed, Sanur.

Restoran Man Shed menggunakan mayoritas material upcycle dalam desain interiornya. Demi menciptakan tema garage khusus untuk segmentasi laki-laki yang hobby otomotif, keseluruhan fasilitas di interior menggunakan kendaraan bekas sebagai elemennya. Dalam aplikasi tersebut tampak aspek kreatifitas desainer dalam transformasi material masih minim, lebih ke penataan dan pemanfaatan produk yang telah terpakai yang ditempatkan dan ditata sedemikian rupa untuk menciptakan suasana seperti sebuah bengkel. Transformasi bentuk diaplikasikan pada fasilitas utama seperti kursi dan meja makan. Karakteristik material tampak jelas dengan mempertahankan efek korosi, penggunaan dan kerusakan yang justru menjadi nilai estetis tertentu dalam elemen fasilitas tersebut.

\section{Warung Pepe, Kuta}

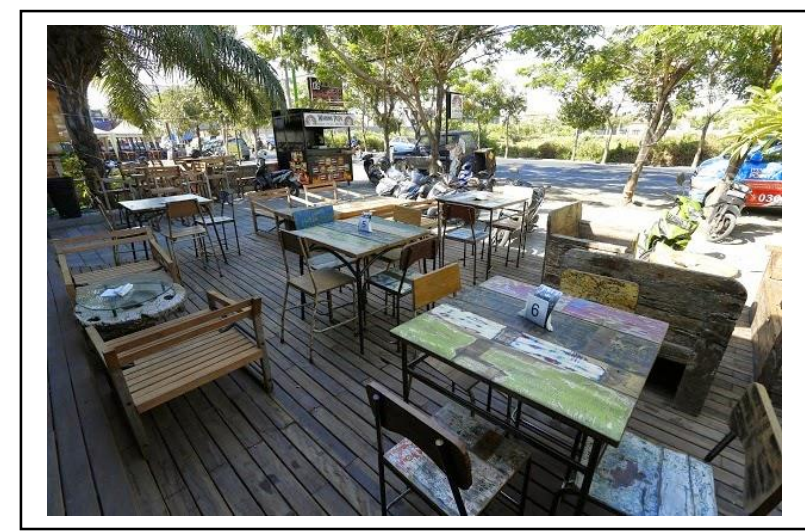

Gambar 2. Interior Warung Pepe, Kuta.

Aplikasi material upcycle pada Warung Pepe, Kuta telah menggunakan aspek material upcycle kayu yang telah ditransformasikan ke dalam wujud fasilitas restoran. Fasilitas Material upcycle tersebut ditempatkan pada sisi eksterior restoran dan menjadi aksen tersendiri dari keseluruhan interior restoran. Pada Warung Pepe tidak semua fasilitas menggunakan material upcycle secara murni, namun dikondisikan suasana yang dibangun dari pemilihan elemennya yaitu upcycle look khas desain interior urban. Dengan penempatan memorabilia, typography, poster yang mengacu ke tema urban youthness.

\section{Crate Cafe, Canggu}

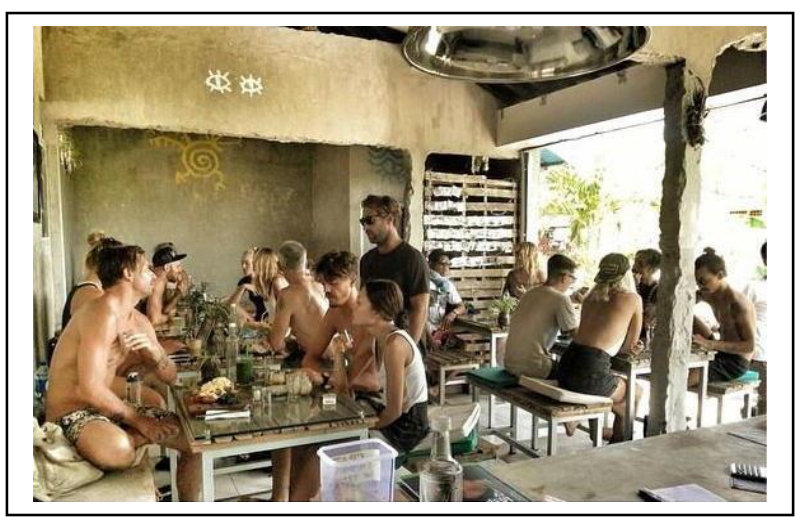

Gambar 3. Interior Crate Cafe, Canggu.

Cafe untuk para surfer di daerah tujuan surfer di Bali ini, visualisasi desain interiornya terkesan urban brutalism. Kesan tersebut didapat dari finishing elemen pembentuk yang terkesan unpolished dengan membiarkan masih tanpa 'sentuhan' dan kasar. Hampir semua fasilitas menggunakan material upcycle dengan minim kreasi hanya penguatan konstruksi semata. Pengaplikasian material upcycle tersebut menguatkan tema surf camp yang tanpa aturan, terbuka, bebas dan ramah. 


\section{Potato Head Restaurant, Petitenget}

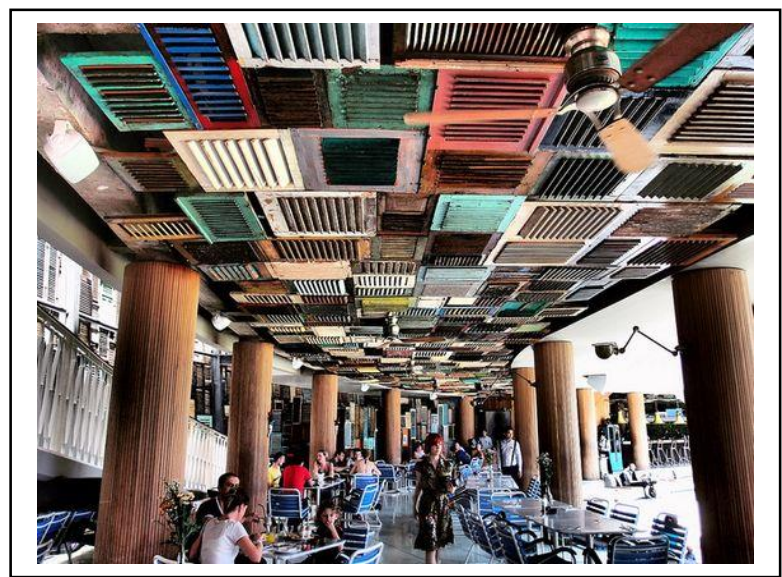

Gambar 4. Interior Potato Head Restaurant, Petitenget.

Restoran yang cukup ikonik akibat pengaplikasian material upcycle pada elemen interior dan arsitektural ini telah menjadi rujukan dalam pengaplikasian material upcycle pada desain interior. Jendela (shutter) bekas rumahan diaplikasikan pada fasad dan juga plafon desain interior. Variasi warna, tekstur, garis dan bidang menjadikan suatu aksen tersendiri dalam desain interior gudang tersebut.

\section{PEMBAHASAN}

Dari beberapa sampel di atas dan dikomparasikan dengan literatur sebelumnya maka didapat aplikasi upcycling di ruang komersial, lihat tabel 1.

Tabel 1. Aplikasi Upcycling dalam Sampel

\begin{tabular}{|c|c|c|c|}
\hline & Sustainability & $\begin{array}{c}\text { Environmental } \\
\text { Wise }\end{array}$ & $\begin{array}{l}\text { Creative } \\
\text { Approach }\end{array}$ \\
\hline Man Shed & +++ & +++ & +++ \\
\hline $\begin{array}{l}\text { Warung } \\
\text { Pepe }\end{array}$ & - & - & - \\
\hline Crate Cafe & + & ++ & ++ \\
\hline Potato Head & + & - & ++ \\
\hline
\end{tabular}

Pada tabel diatas dapat dilihat Man Shed Restaurant yang menggunakan prinsip upcycling secara maksimal dalam desain interiornya. Man Shed secara kreatif dan total menggunakan material upcycle dalam mendukung tema dan konsep desain interior. Material upcycle tersebut menjadi aksen penting dalam keseluruhan elemen desain interior restoran dan memperkuat visualisasi konsep desain interiornya. Dalam konteks proses redesain dari produk buangan tersebut yang mengikuti prinsip regenerasi desain dalam proses upcycle lihat tabel 2.

Tabel 2. Prinsip Regenerasi Desain

\begin{tabular}{|c|c|c|c|c|c|}
\hline & $\begin{array}{c}\text { Prinsip } \\
\text { Penguatan } \\
\text { Nilai }\end{array}$ & $\begin{array}{c}\text { Prinsip } \\
\text { Tanpa } \\
\text { Sisa }\end{array}$ & $\begin{array}{c}\text { Prinsip } \\
\text { Durabilitas } \\
\text { dan } \\
\text { Lingkungan }\end{array}$ & $\begin{array}{c}\text { Prinsip } \\
\text { Kontrol } \\
\text { Biaya }\end{array}$ & $\begin{array}{c}\text { Prinsip } \\
\text { Estetika } \\
\text { Masyarakat }\end{array}$ \\
\hline Man Shed & +++ & +++ & +++ & +++ & +++ \\
\hline $\begin{array}{c}\text { Warung } \\
\text { Pepe }\end{array}$ & + & - & + & ++ & ++ \\
\hline Crate Cafe & + & +++ & ++ & +++ & + \\
\hline $\begin{array}{c}\text { Potato } \\
\text { Head }\end{array}$ & +++ & + & ++ & +++ & +++ \\
\hline
\end{tabular}

Pada tabel di atas dapat dilihat Man Shed Restaurant kembali menduduki tempat pertama dalam penerapan prinsip regenerasi tersebut. Prinsip regenerasi desain dijadikan tema pokok dalam pengembangan visualisasi desain interior restorannya. Material buangan dijadikan point of interest dari restoran tersebut. Kesan "sampah" dari material buangan tersebut justru menjadi material yang bernilai estetis.

\section{SIMPULAN}

Dari pemaparan di atas dapat dipahami bahwa, restoran sebagai tempat menjual makanan dan minuman yang mengedepankan faktor higienitas, pada penerapan materialitasnya sesuai dengan objek kasus di atas, membuka peluang untuk menampilkan material buangan. Material buangan yang diaplikasikan kembali (upcycling) memberikan pengayaan materialitas dalam desain interior. Dari objek kasus Man Shed dapat dipahami bahwa pertimbangan dalam memilih materialitas dalam kontruksi citra desain interior antara lain:

1. Uniqueness: Yaitu penerapan material buangan yang tidak lazim digunakan sebagai elemen interior namun secara faktual dapat digunakan. Contohnya: material buangan body vespa sebagai meja makan.

2. Tekstur: Tekstur karat, overuse dan kondisi warna asali pada material buangan justru menjadi nilai tambah ketika diaplikasikan sebagai material desain interior. Aspek kenangan terhadap material buangan tersebut menjadi nilai tersendiri yang menguatkan aspek estetika material tersebut.

3. Transformasi Bentuk: Pertimbangan penggunaan material buangan dalam desain interior adalah faktur bentuk ikonik dan peluang untuk transformasi bentuk (flexibility) ketika akan dialih fungsikan kembali sesuai dengan kreatifitas desainernya. Nilai kreatifitas dari penerapan material upcycle tersebut memberikan nilai tambah pada aspek materialitas material bungan tersebut.

4. Memorabilia: Aspek nilai kenangan dari material buangan memberikan nilai ekonomis dan psikologis yang mempengaruhi aspek materialitas dalam material buangan tersebut. Material buangan dari brand ikonik yang mempunyai nilai sentimentil dan aspek kesejarahannya tertentu turut memberikan nilai tambah pada aspek materialitasnya.

5. Kesesuaian dengan Konsep: Dasar pemilihan material disesuaikan dengan konsep desain interior dan material buangan digunakan sebagai penguat visualisasi desain. Man Shed sesuai dengan namanya konsep desainnya ingin menampilkan tempat kumpul bagi civitas lelaki yang mempunyai hobby otomotif dan dunia perbengkelan. Kesesuaian dengan konsep tersebut, penggunaan material buangan dipandang tepat untuk mendukung konsep desain tersebut.

\section{REFERENSI}

[1] Bramston, David, 2009, Material Thoughts, Switzerland: AVA Academica.

[2] Gesimondo, Nancy dan Postell, Jim, 2011, Materiality and Interior Construction, New Jersey: John Willey \& Sons. 
[3] Ali, Nawwar Shuriah dan Khairuddin, Nuur Farhana dan Abidin, Shahriman Zainal, 2013, Upcycling: ReUse and Recreate Functional Interior Space Using Waste Material, Paper on International Conference On Engineering And Product Design Education 5 \& 6 September 2013, Dublin Institute Of Technology, Dublin, Ireland.

[4] Karana, Elvin dan Pedgley, Owain dan Rognoli, Valentina, 2014, Materials Experience: Fundamentals of Material and Design, Oxford: Elsevier.

[5] Xu, Jiang dan Gu, Ping, 2015, Five Principles of Waste Product Redesign under the Upcycling Concept, International Forum on Energy, Environment Science and Materials (IFEESM 2015), Atlantis Press.

[6] Binggeli, Corky, 2014, Material For Interior Environments, New Jersey: John Willey \& Sons.

[7] Farelly, Lorraine, 2009, Basic Architecture 02: Construction + Materiality, Switzerland: AVA Publishing SA. 